\title{
Two structurally discrete GH7-cellobiohydrolases compete for the same cellulosic substrate fiber
}

\author{
Fernando Segato ${ }^{1,4}$, André R L Damasio ${ }^{1,5}$, Thiago Augusto Gonçalves ${ }^{4}$, Mario T Murakami ${ }^{3}$, Fabio M Squina ${ }^{4}$, \\ Maria de Lourdes T M Polizeli ${ }^{6}$, Andrew J Mort ${ }^{2}$ and Rolf A Prade ${ }^{1,4^{*}}$
}

\begin{abstract}
Background: Cellulose consisting of arrays of linear beta-1,4 linked glucans, is the most abundant carbon-containing polymer present in biomass. Recalcitrance of crystalline cellulose towards enzymatic degradation is widely reported and is the result of intra- and inter-molecular hydrogen bonds within and among the linear glucans. Cellobiohydrolases are enzymes that attack crystalline cellulose. Here we report on two forms of glycosyl hydrolase family 7 cellobiohydrolases common to all Aspergillii that attack Avicel, cotton cellulose and other forms of crystalline cellulose.
\end{abstract}

Results: Cellobiohydrolases Cbh1 and CeID have similar catalytic domains but only Cbh1 contains a carbohydrate-binding domain (CBD) that binds to cellulose. Structural superpositioning of Cbh1 and CelD on the Talaromyces emersonii Cel7A 3-dimensional structure, identifies the typical tunnel-like catalytic active site while Cbh1 shows an additional loop that partially obstructs the substrate-fitting channel. CelD does not have a CBD and shows a four amino acid residue deletion on the tunnel-obstructing loop providing a continuous opening in the absence of a CBD. Cbh1 and CelD are catalytically functional and while specific activity against Avicel is 7.7 and $0.5 \mathrm{U} \cdot \mathrm{mg}_{\text {prot }}{ }^{-1}$, respectively specific activity on $p \mathrm{NPC}$ is virtually identical. Cbh1 is slightly more stable to thermal inactivation compared to CelD and is much less sensitive to glucose inhibition suggesting that an open tunnel configuration, or absence of a CBD, alters the way the catalytic domain interacts with the substrate. Cbh1 and CelD enzyme mixtures on crystalline cellulosic substrates show a strong combinatorial effort response for mixtures where Cbh1 is present in 2:1 or 4:1 molar excess. When CelD was overrepresented the combinatorial effort could only be partially overcome. CelD appears to bind and hydrolyze only loose cellulosic chains while Cbh1 is capable of opening new cellulosic substrate molecules away from the cellulosic fiber.

Conclusion: Cellobiohydrolases both with and without a CBD occur in most fungal genomes where both enzymes are secreted, and likely participate in cellulose degradation. The fact that only Cbh1 binds to the substrate and in combination with CelD exhibits strong synergy only when Cbh1 is present in excess, suggests that Cbh1 unties enough chains from cellulose fibers, thus enabling processive access of CelD.

Keywords: Cellobiohydrolase, Cellobiohydrolase I, Cellobiohydrolase D, Aspergillus niveus, Aspergillus fumigatus, Crystalline cellulose breakdown, Biofuels, Cellulases, Biomass decomposition

\footnotetext{
* Correspondence: prade@okstate.edu

${ }^{1}$ Department of Microbiology \& Molecular Genetics, Oklahoma State

University, Stillwater, OK, USA

${ }^{4}$ Laboratório Nacional de Ciência e Tecnologia do Bioetanol (CTBE), Centro

Nacional de Pesquisas em Energia e Materiais, Campinas, Sao Paulo, Brazil

Full list of author information is available at the end of the article
}

\section{Biomed Central}

(c) 2012 Segato et al.; licensee BioMed Central Ltd. This is an Open Access article distributed under the terms of the Creative Commons Attribution License (http://creativecommons.org/licenses/by/2.0), which permits unrestricted use, distribution, and reproduction in any medium, provided the original work is properly cited. 


\section{Background}

Biofuel generation from sources such as cornstarch, sugarcane or sweet sorghum syrups, produces large amounts of biomass waste products. For example, over $90 \%$ of the plant is unused in the case of ethanol production from cornstarch [1-3]. Current commercial enterprises produce ethanol from cornstarch, sugar cane or sweet sorghum syrups and large amounts of waste biomass accumulate alongside refineries and most of them are not recycled. Biofuels production would therefore be significantly more efficiently utilized if this biomass could be converted into fermentable sugars.

Biomass polysaccharides consist of cellulose, hemicellulose and pectin. Cellulose is a linear, crystalline selfassembled nanofiber formed from the linear polymer containing exclusively glucose monomers linked through $\beta$-1,4-glycosydic bonds [1-4]. Recalcitrance of cellulose towards enzymatic degradation is a widely reported phenomenon $[1,5,6]$ and is the result of the wide range of possible intra- and inter-molecular hydrogen bonds within and among linear cellulose molecules assuming crystalline or amorphous cellulosic nanofiber structures. Cell walls from different plants contain various amounts of crystalline/amorphous cellulose fibers [7], reflected by the relative crystalinity index (RCI).

Because cellulose is structurally complex and crystalline in nature, it is recalcitrant towards microbial or enzymatic attack. Unfortunately, current pretreatment methods - e.g., acid hydrolysis [8,9] or pyrolysis [10,11], generate compounds that inhibit subsequent fermentation. Enzymatic hydrolysis of cellulose results in glucose the universal carbon source for all organisms to drive oxidative metabolism including the production of biofuels, chemicals and pharmaceuticals.

A complete enzymatic cellulose degrading system consists of at least three related partially redundant biochemical reactions. Endo-glucanases (EC 3.2.1.4) randomly hydrolyze internal glycosydic bonds to decrease the length of the cellulose chain and multiply polymer ends [12-14]. Exo-glucanases (EC 3.2.1.91) split-off cellobiose from cellulose termini [15-17] and $\beta$-glucosidases (EC 3.2.2.21) hydrolyze cellobiose and oligomers to render glucose [18-20]. All three types of enzymes have similar catalytic domains all splitting the $\beta-1,4$-glycosidc bond between glucose molecules, however they differ in their binding and substrate interaction domains resulting in cooperation and synergism in releasing glucose [21-23].

Exo-glucanases hydrolyze cellulose chains by removing cellobiose either from the non-reducing end (GH6, EC 3.2.1.91) or reducing end (GH7, EC 3.2.1.176), which in both cases results in the release of reducing sugars (cellobiose) but little polymer length reduction [24]. In fungi, exo-glucanases are commonly known as $1,4-\beta$-D-glucan cellobiohydrolases [25]. The main characteristic of a cellobiohydrolase is its processive action on individual cellulose chains by reiterated release of cellobiose [24,26-32].

The catalytic domain (CD) of a typical cellobiohydrolase forms a channel-shaped cavity topped by several flexible loops resulting in a tunnel like structure [33-39], which is frequently connected through a linker to a carbohydrate binding domain (CBD) [40,41]. CBDs are thought to bind to the crystalline cellulosic fiber sliding down the cellulosic surface $[6,42]$ and carrying the CD with it. Three tyrosine residues on the CBD hydrophobic surface align with the cellulose chain adjacent to the reducing end and a fourth tyrosine residue moves from its internal position to form van der Waals interactions with the cellulose surface resulting in an induced change near the surface allowing the CBD to progress $[16,40]$.

From a comprehensive bioinformatics survey of seven Aspergillii completely sequenced genomes, we found between three and five genes encoding cellobiohydrolases, typically two in each of the CAZy families GH6 and GH7, respectively. Remarkably, for each GH family 6 or 7 fungal cellobiohydrolase examined, one enzyme was linked to a CBD and a second was not.

Here we describe two GH7-cellobiohydrolases, Cbh1 and CelD from Aspergillus niveus. The structural differences between these two enzymes were the lack of a CBD in CelD and a conserved loop that obstructed the catalytic tunnel in enzymes that were linked to a CBD, but missing in enzymes that did not link to a CBD, ensuring that the tunnel was always open. These structural differences reflected directly on kinetic properties, thermostability, inhibition by glucose and cellobiose and the way these proteins interacted with crystalline substrate molecules. We hypothesize that the cellobiohydrolase linked to a CBD is competent to release cellulosic chains from the crystalline nanofiber and the cellobiohydrolase without a CBD can only use loose ends, without the aid of a CBD.

\section{Results}

Aspergillii hold precisely two GH7-cellobiohydrolases, one with and another without a cellulose-binding domain

Fungi and bacteria produce enzymes that at least partially degrade plant cell wall polysaccharides [43,44]. More often than not, cellulase-encoding genes appear as multiple copies in the genome of sequenced microorganisms and enzymes occur as functionally redundant with overlapping biochemical functions.

Cellobiohydrolases belonging to CAZy family GH7, attack crystalline forms of cellulose from the reducing ends of cellulose chains generating cellobiose [13,21,24,27]. Table 1 shows that the genome of almost every Aspergillus precisely encodes two GH7-cellobiohydrolases, one with, 
Table 1 Genome wide distribution of gh7cellobiohydrolases

\begin{tabular}{|c|c|c|}
\hline \multirow[t]{3}{*}{ Aspergillii } & \multicolumn{2}{|c|}{ gh7-cellobiohydrolases } \\
\hline & no CBM & CBM \\
\hline & Prot ID Locus tag & Prot ID Locus tag \\
\hline A. clavatus NRRL1 & $\begin{array}{l}\text { XP_001272622 } \\
\text { ACLA_088870 }\end{array}$ & $\begin{array}{l}\text { XP_001272622 } \\
\text { ACLA_085260 }\end{array}$ \\
\hline A. fumigatus Af293 & $\begin{array}{c}\text { XP_750600 AFUA } \\
6 \mathrm{G} 07070\end{array}$ & $\begin{array}{c}\text { XP_751044 AFUA } \\
\text { 6G11610 }\end{array}$ \\
\hline A. nidulans FGSC A4 & $\begin{array}{c}\text { XP_662780 } \\
\text { AN5176 }\end{array}$ & XP_658098 AN0494 \\
\hline A. niger CBS 513.88 & $\begin{array}{l}\text { XP_001392008 } \\
\text { ANI_1_2134064 }\end{array}$ & $\begin{array}{l}\text { XP_001389576 } \\
\text { ANI_1_1574014 }\end{array}$ \\
\hline A. terreus NIH 2624 & $\begin{array}{l}\text { XP_001212905 } \\
\text { ATEG_03727 }\end{array}$ & $\begin{array}{c}\text { XP_001214180 } \\
\text { ATEG_05002 }\end{array}$ \\
\hline \multirow[t]{2}{*}{ A. oryzae RIB40 } & $\begin{array}{l}\text { XP_001818879 } \\
\text { AOR_1_608164 }\end{array}$ & none \\
\hline & $\begin{array}{l}\text { XP_001727881 } \\
\text { AOR_1_1654194 }\end{array}$ & none \\
\hline \multirow[t]{2}{*}{ A. flavus NRRL-3357 } & $\begin{array}{l}\text { XP_002380314 } \\
\text { AFLA_067550 }\end{array}$ & none \\
\hline & $\begin{array}{l}\text { XP_002376207 } \\
\text { AFLA_021870 }\end{array}$ & none \\
\hline $\begin{array}{r}\text { P. chrysogenum } \\
\text { W54-1255 }\end{array}$ & $\begin{array}{l}\text { CAP94773 } \\
\text { Pc18g05490 }\end{array}$ & CAP85526 Pc20g01970 \\
\hline $\begin{array}{r}\text { Neurospora } \\
\text { crassa OR 74A }\end{array}$ & $\begin{array}{l}\text { XP_957090 } \\
\text { NCU05104 }\end{array}$ & XP_962498 NCU07340 \\
\hline $\begin{array}{l}\text { Phanerochaete } \\
\text { chrysosporium }\end{array}$ & $\begin{array}{l}\text { CAA38274 } \\
\text { Pccbh-1 }\end{array}$ & CAA38275 Pccbh 1-2 \\
\hline Hypocrea jecorina & none & GUX_1TRIRE cbn1 \\
\hline $\begin{array}{r}\text { Trichoderma viride } \\
\text { (Hypocrea rufa) }\end{array}$ & none & BAA36215 cbh1 \\
\hline Hypocrea virens & none & ACF93800 cbh1 \\
\hline
\end{tabular}

and another without a CBD. The one exception is Aspergillus flavus/A. oryzae (both genomes contain an almost identical nucleotide sequence [45]), which encode two GH7-cellobiohydrolase, both with no CBD. However, it is not clear if another gene with a CBD exists or the CBD domain has not yet been annotated. Other fungi such as Neurospora crassa OR74, Penicillium chrysogenum W54-1255 and Phanerochaete chrysosporium have a two-set of GH7-cellobiohydrolases, while Hypocrea jecorina, Hypocrea rufa, Hypocrea virens and other Trichodermales appear to contain only one GH7-cellobiohydrolase, all with a CBD.

$A$. niveus a filamentous fungus analogous to $A$. fumigatus (the genomic DNA sequence is up to $97 \%$ identical) grew at high temperatures, up to $50^{\circ} \mathrm{C}$, on medium containing complex carbon sources such as cellulose and hemicellulose. As expected, the genome of $A$. niveus encoded two GH7-cellobiohydrolases: Cbh1-like 1,4-beta-D-glucan cellobiohydrolase with a linker and CBD and a CelD-like 1,4-beta-D-glucan cellobiohydrolase with no linker and
CBD. Genes, $c b h 1$ and $c e l D$ were expressed and proteins secreted into the medium when the fungus was grown on cellulose (e.g., Avicel) as the carbon source (data not shown).

Both $c b h 1$ and celD genes have been expressed as client proteins in $A$. nidulans, under the control of the maltose promoter, translated and secreted via the glucoamylase signal peptide [46] where they exhibited "in situ" activity towards carboxymethylcellulose (Figure 1A). Both proteins were purified by ion exchange followed by gel filtration chromatography and used for comprehensive biochemical analysis (See Methods and Additional file 1: Table S1).

The Cbh1 and CelD catalytic domains share $72 \%$ identity and $82 \%$ similarity in their amino acid sequences. The main difference between these proteins is the presence of a cellulose-binding domain in Cbh1 and the absence of such a domain in CelD. The objective of this study was to investigate the mechanistic differences between these two enzymes.

\section{Minor structural differences in Cbh1 and CelD are catalytically relevant}

Cbh1 and CelD catalytic domains (CD) were modeled based on the 3D-structural template derived from Talaromyces emersonii cellobiohydrolase 1 (PDBID: 1Q9H, [47]). Modeled structures were subjected to energy minimization and final models presented highquality local and overall stereochemistry with approximately $98 \%$ of amino acid residues lying in allowed regions of the Ramachandran plot (Figure 1B-E).

The Cbh1 and CelD catalytic core comprises a typical CaZy GH7 family $\beta$-sandwich surrounded by numerous surface loops, which outline the substrate-binding channel (Figure 1B-E). The native T. emersonii structure presented a disordered loop encompassing the amino-acid segment 190-200. This sequence was fully conserved among all other Cbh1 proteins (Figure 1F), and likely became structured upon substrate binding similarly, to what has been reported for other glycosyl hydrolases [48]. Structural superposition resulted in a RMSD value of $0.15 \mathrm{C} \alpha$ for $\mathrm{C} \alpha$ atoms indicating high conservation of Cbh1 and CelD three-dimensional structures. The catalytically relevant residues and the substrate channel are fully conserved including Trp38, Tyr168, Asp170, Glu209, Asp211, Glu214, Trp371 and Trp380 (Figure 1C). The only significant difference was at the entrance of the catalytic tunnel formed by loops 43-63, 94-103 and 190-200 that partially blocked the catalytic channel in Cbh1, due to a four-residue insertion in the 94-103 loop (Figure 1C and 1F). In all CelD proteins, this four amino acid insertion is missing (Figure 1F) and CelD proteins do not have a CBD thus suggesting that in the absence 

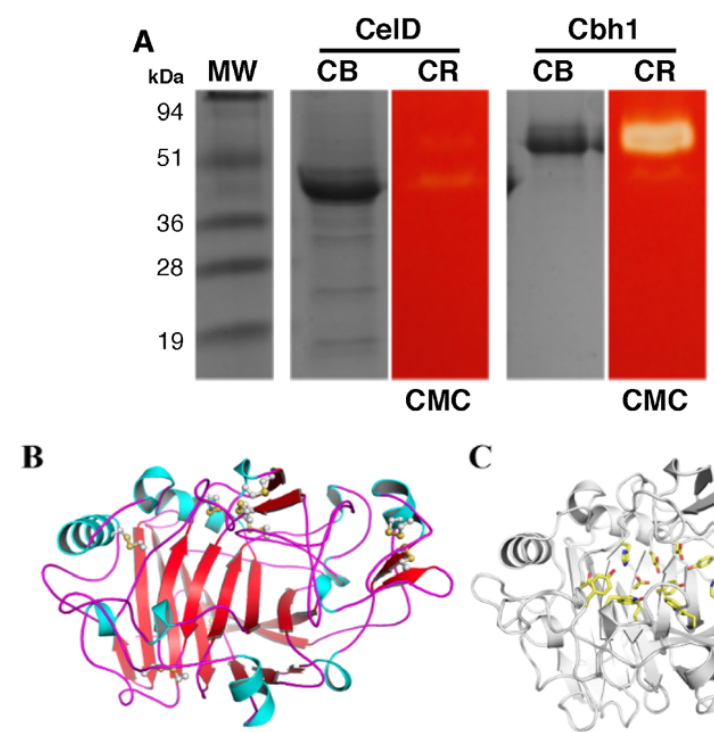

C
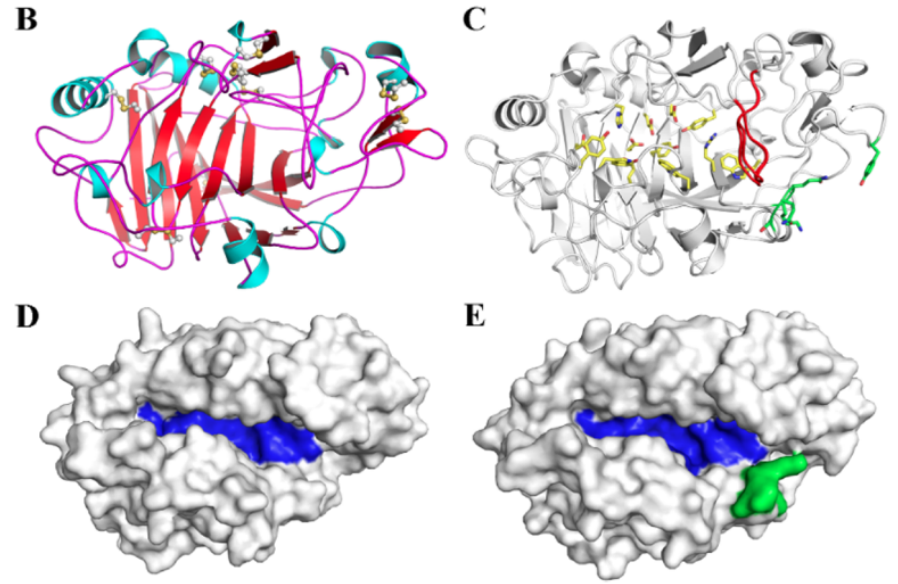

$\mathbf{F}$

PROTEINS WITH NO CELLULOSE BINDING DOMAIN - CelD LIKE

A clavatus ACLA 08887096 TYGVTADGSSLKLNFVTS----ANVGSRLYL 128-205 SDNDKNAGVGGYG 217 A fumigatus AFUA 6G07070 96 TYGVTTSGSELKLSFVTG----ANVGSRLYL 128-205 SSSDKNAGVGGHG 217 A oryzae AOR 1165419496 TYGVTTSGDALTLOFVTG-- ANIGSRLYL 128-205 SDSDKNAGVGGG 217 96 TYGVTISGDLLTLQVTG--ANIGSRLYL 128-205 SDSDKNAGVGGH 217 96 TYGVTISGDALTLQFVG--ANIGSRLYL 128-205 SDSDKNAGVGGHG 217 A terreus ATEG 03727 96 TYGITTSGDALTLTFVTG----ENVGSRVYL 128-205 SDNDKNAGVGGHG 217 A nidulans AN 5176 96 TYGITSNGDSLTLKFVTG----SNVGSRVYL 128-205 SDSDANAGVGGMG 217 A niger ANI 1213406496 TYGVTTDGDSLTLKFVTG----SNVGSRLYL 128-205 SSNNDNTGIGNHG 217 P chrysogenum Pc18g05490 96 TYGATTSGNALTLSFVTG----ANVGSRLFL 128-205 SENDKNAGVGGHG 217

PROTEINS WITH CELLULOSE BINDING DOMAIN - Cbh1 LIKE

\begin{tabular}{|c|c|c|c|c|}
\hline A clavatus ACLA 085260 & 96 TYGATTSGNALSLKFVTQSQQ-KNIGSRLYM & $128-205$ & SS-DANAGNGGHG & 217 \\
\hline A fumigatus AFUA $6 \mathrm{G} 11610$ & 96 TYGVTASGNSLRLNFVTTSQQ-KNIGSRLYM & $128-205$ & SSNDANAGTGNHG & 217 \\
\hline oryzae AOR 1608164 & TYGITTSGSEVRLNFVTSNSNGKNVGSRVYM & $128-205$ & STNNANTGTGNHG & 217 \\
\hline flavus AFLA 067550 & 96 TYGITTSGSEVRLNFVTSNSNGKNVGSRVYM & $128-205$ & STNNANTGTGNHG & 217 \\
\hline terreus ATEG 05002 & 96 TYGVTTSGNSLRLNFVTQASQ-KNIGSRLYL & $128-205$ & SANDANAGTGNHG & 217 \\
\hline nidulans AN 0494 & 96 TYGITTSGSSLRLNFVTQSQQ-KNIGSRVYL & $128-205$ & SDTNPNGGVGNHG & 217 \\
\hline niger ANI 11574014 & 96 TYGVTTSGSELRLNFVTQGSS-KNIGSRLYL & $128-205$ & SSNNVNTGVGDHG & 217 \\
\hline chrysogenum Pc20g01970 & 96 TYGVTASGSSLRLNFVTQASQ-KNIGSRLYL & $128-205$ & SSSDVNGGTGSYG & 217 \\
\hline PROTEINS WITH CE & BINDING DOMAIN ONLY & & & \\
\hline$H$ jecorina cbh 1 & 96 TYGVTTSGNSLSIGFVTQSAQ-KNVGARLYL & & & \\
\hline$T$ viride cbh 1 & 96 TYGVTTSADSLSIGFVTQSAQ-KNVGARLYL & $128-205$ & SSNNANTGIGGHG & 217 \\
\hline$H$ virens cbh1 & 96 TYGITTSSDSLTINFVTQS----NVGARLYL & $128-205$ & SSNNANTGIGGHG & 217 \\
\hline P chrysosporium Pccbh11 & 96 TYGITTSGSALRLQFVTGT----NIGSRVFL & $128-205$ & TS--ATTGTGSYG & 217 \\
\hline P chrysosporium Pccbh12 & TFGILPSGTSVTLRPVDG-------LGLRLFL & $128-205$ & TT--ATTGTGFFG & 217 \\
\hline
\end{tabular}

Figure 1 Structural overview of Cbh1 and CelD catalytic homologs active on cellulosic substrates. Panel A SDS-PAGE comassie-blue (CB) protein and carboxymethylcellulose congo-red (CR) enzyme activity staining of secreted Cbh1 and CelD proteins recovered from two-day shake-flask cultures. Cbh1 showed a strong activity against CMC while CelD showed lesser activity on CMC. Restraint-based modeling of Cbh1 and CelD identified a flexible catalytic loop and a lid-like loop obstructing the substrate tunnel. Panel B, cartoon representation of CelD, colored by secondary structure elements. Disulphide bonds are shown in ball-and-stick representation. Panel C, CelD/Cbh1 catalytic domain structural overlay. The active-cleft residues are shown as stick carbon atoms in yellow. The flexible catalytic loop, common to all GH7 cellobiohydrolases is shown in red and the three-residue lid-type insertion within the 94-103 loops only present in Cbh1 is drawn as sticks with carbon atoms in green. CelD (Panel D) and Cbh1 (Panel E) surface model prediction highlighting the catalytic substrate tunnel in blue and the obstructing lid-type loop in green. For a clearer view of the substrate channel, some residues at the protein surface were omitted. Alignment of the 94-103 lid-like and flexible catalytic loops of GH7-cellobiohydrolases (Panel F). All CelD like proteins with no CBD show a four amino acid deletion that opens the catalytic tunnel (shown in $\mathbf{D}$ and $\mathbf{E}$ ). 
Table 2 Cbh1 and CelD kinetic properties on crystalline cellulosic substrates

\begin{tabular}{ccccccc}
\hline $\begin{array}{c}\text { Kinetic } \\
\text { parameter }\end{array}$ & \multicolumn{2}{c}{ Avicel } & Cotton cellulose & \multicolumn{2}{c}{ pNPC } \\
\cline { 2 - 7 } & Cbh1 & CelD & Cbh1 & CelD & Cbh1 & CelD \\
\hline $\mathrm{V}_{\text {max }}(\mu \mathrm{mol} / \mathrm{min})$ & 24.81 & 3.39 & 20.62 & 3.95 & - & - \\
& \pm 0.75 & \pm 0.35 & \pm 0.62 & \pm 0.06 & & \\
$\mathrm{~K}_{\mathrm{m}}(\mathrm{mg} / \mathrm{mL})$ & 18.27 & 43.50 & 18.83 & 16.60 & - & - \\
& \pm 1.97 & \pm 6.39 & \pm 1.99 & \pm 0.97 & & \\
$\mathrm{~K}_{\text {cat }}\left(\mathrm{min}^{-1}\right)$ & 22.20 & 2.62 & 18.45 & 3.05 & - & - \\
\hline $\mathrm{K}_{\text {cat } / \mathrm{K}_{\mathrm{m}}}$ & 1.22 & 0.06 & 0.98 & 0.18 & - & - \\
\hline $\mathrm{U} \mathrm{mg} \mathrm{prot}^{-1}$ & 7.66 & 0.49 & 4.57 & 1.19 & 26.20 & 27.31 \\
& \pm 1.21 & \pm 0.04 & \pm 0.02 & \pm 0.06 & \pm 0.20 & \pm 1.40 \\
\hline
\end{tabular}

${ }^{*}$ Specific activity (U.mg prot ${ }^{-1}$ ) determined with $10 \mathrm{mg} / \mathrm{ml}$ avicel cotton cellulose or $18 \mathrm{mM} \mathrm{pNPC}$ at $40 \mathrm{C}$ FOR $120 \mathrm{mins}$.

of a CBD, the catalytic domain only functions if the substrate channel is open.

\section{Cbh1 and CelD are catalytically functional}

Purified Cbh1 and CelD were incubated in the presence of increasing amounts of two crystalline cellulosic substrates, Avicel and cotton cellulose and the specific velocity was determined after a $120 \mathrm{~min}$ reaction period (For the Michaelis Menten plot refer to Additional file 2: Figure S1). Table 2 shows both, Cbh1 and CelD responding to increasing amounts of crystalline cellulose substrates, the number of substrate molecules converted, $\mathrm{k}_{\text {cat }}$, over time (minutes) significantly diverged between Cbh1 and CelD; while Cbh1 turned over 22.20 and 18.45 Avicel or cotton cellulose molecules, respectively, CelD turned over only 2.62 and 3.05 molecules respectively. Thus, Cbh1 was about 6 to 8 fold more efficient in hydrolyzing crystalline cellulosic substrates. This difference was also reflected in the determined catalytic efficiency $\mathrm{K}_{\mathrm{cat}} / \mathrm{K}_{\mathrm{m}}$, which hovers from 1.22 to 0.98 and 0.06 to 0.18 depending on the substrate, respectively (see Table 2). Specific activity for both proteins reflected the catalytic differences as well as the substrate affinities for Avicel and cotton cellulose except when assayed with $p$-nitrophenyl- $\beta$-D-cellobioside ( $p \mathrm{NPC}$ ) where specific activity was identical, suggesting that Cbh1 and CelD catalytic domains function equally. However they differ in the way they interact with insoluble polymeric substrates.

\section{Only Cbh1 binds to cellulose}

Because CelD does not have a CBD and is biochemically active, we hypothesized that CelD could associate with Cbh1 in solution and use the Cbh1 CBD to slide along cellulose chains. However, our experiment (Figure 2) shows that CelD does not bind to cellulose alone or in combination with Cbh1, thus ruling out an association between these two enzymes in natural substrate interactions.

\section{Thermal inactivation leads to differential protein unfolding}

To study thermal inactivation, Cbh1 and CelD were incubated at various temperatures in the absence of substrate in $50 \mathrm{mM}$ ammonium acetate buffer for $40 \mathrm{~min}$ and residual activity was determined with $p$ NPC. Figure 3 shows that Cbh1 was slightly more stable to thermal inactivation when compared to the inactivation of CelD, suggesting that the presence of a CBD, only present in Cbh1, had a thermo protection effect similar to that observed for other proteins with CBD's $[49,50]$.

\section{Differential glucose inhibition implies two differentially adapted catalytic domains}

Catalytic inhibition studies of Cbh1 and CelD by cellobiose and glucose, were carried out with purified enzymes and $p$ NPC as a substrate (Figure 4). In the presence of $5 \mathrm{mM}$ cellobiose, $90 \%$ of the activity for both enzymes was inhibited. Addition of glucose however, had a differential effect: with $50 \mathrm{mM}$ of glucose, Cbh1 retained $75 \%$ of its initial activity while CelD retained only $55 \%$. In the presence of $100 \mathrm{mM}$ of glucose, Cbh1 retained $80 \%$ of its initial activity and CelD had lost more than $50 \%$. Thus, the rate of $p$-nitrophenyl formation from $p \mathrm{NPC}$ by Cbh1 is less severely affected by the presence of glucose than CelD. The fact that cellobiose does not differentially affect both enzymes, but glucose does, may be a consequence of the structural differences of the catalytic channel.

\section{Cbh1 and CelD combine efforts to hydrolyze the same substrate molecules}

Figure 5 shows that Cbh1/CelD combinations incubated with various cellulosic substrates develop strong synergy only under selective conditions. Cbh1 needs to be added

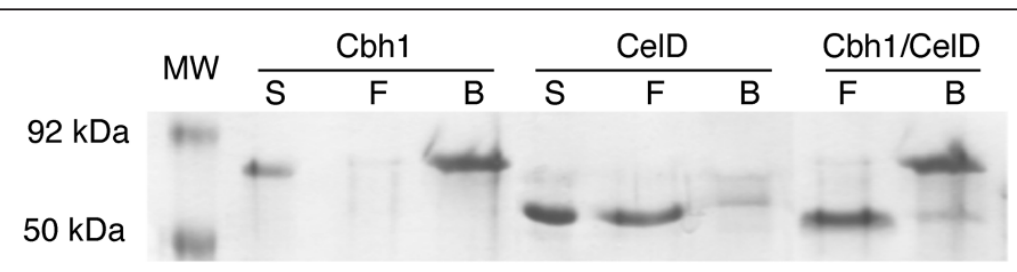

Figure 2 Only Cbh1 binds to cellulose. $20 \mu \mathrm{g}$ of Cbh1, CelD or both (Cbh1/CelD) proteins (S) were incubated with $30 \%$ Avicel for $30 \mathrm{~min}$, the slurry centrifuged, supernatants ( $\mathbf{F}$, free enzyme fraction) collected and enzymes removed from the pellet (B, cellulose-bound proteins) with $1 \%$ SDS and $\beta$-mercaptoethanol, concentrated and analyzed by SDS-PAGE. 


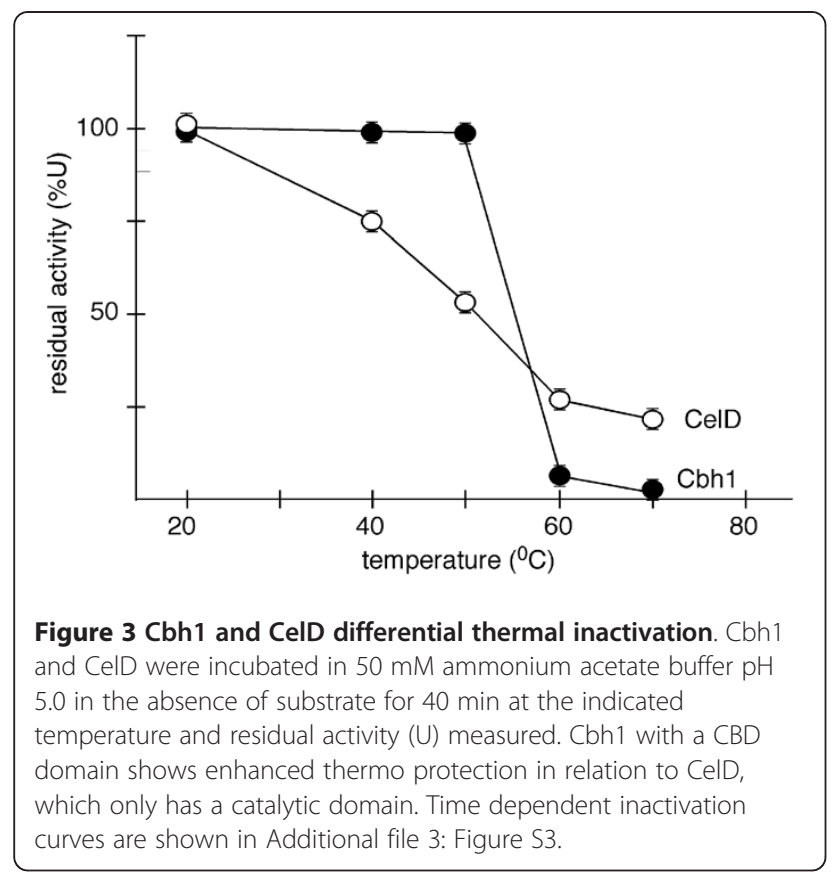

to molar excess of at least 2 fold and the substrate has to be a crystalline form of cellulose, while excess of CelD induces little or no gain in cellulose breakdown.

Cellobiohydrolase activity $(\mathrm{U})$ was determined by mixing $20 \mathrm{nM}(2: 1)$ and $40 \mathrm{nM}$ (4:1) of Cbh1 with $10 \mathrm{nM}$ of CelD or $20 \mathrm{nM}(1: 2)$ and $40 \mathrm{nM}$ (1:4) of CelD with 10 $\mathrm{nM}$ of Cbh1, combined with various forms of crystalline (Figure 5A) and partially hydrated (Figure 5B) cellulosic substrates and the degree of synergy $(D S=a b / a+b)$ was determined [20].

Equimolar Cbh1/CelD mixtures had no combinatorial effect (DS $\leq 1$ ) on cellulose breakdown. Excess of Cbh1 over
CelD resulted in a combinatorial effort (up to 345\%) to attack crystalline (Figure 5A) forms of cellulose while less crystalline forms remained unchanged (Figure 5B). Excess of CelD over Cbh1 resulted in little or no gain in synergy (DS up to 1.91) for crystalline substrates (except 1:4 FP) and activity was inhibited with less crystalline substrates. For details on activity and degree of synergy, see Additional file 3: Figure S2 and Methods.

Thus, molar excess of Cbh1 improved the ability to hydrolyze cellulose chains while excess of CelD only partially improved the activity, which could be correlated to the crystalinity (or available loose cellulose chain ends) of the substrate. When the substrate was PASC, an Avicel artificially swollen with phosphoric acid, there was no apparent combinatorial effort because of the excess number of untied cellulose chains. When the substrate was $\mathrm{CMC}$, a soluble but substituted form of cellulose, there was no consequence when Cbh1 was present in excess or equimolar conditions, however activity was severely affected by the excess of CelD. Interestingly, when incubated alone, Cbh1 was far more active in CMC than was CelD (Figure 1A).

\section{Discussion}

It is a widespread feature of sequenced fungal genomes to contain multiple loci that encode similar plant cell wall degrading enzymes. In Aspergillii, cellobiohydrolase genes are one such example. In A. fumigatus (or the closely related $A$. niveus), one GH6 cellobiohydrolase with a CBD and two GH7 cellobiohydrolases, one with and one without a CBD are present. Here we investigated the functionality of the two GH7 cellobiohydrolases and focus on whether the CBD domain is an essential domain for typical cellobiohydrolase function.
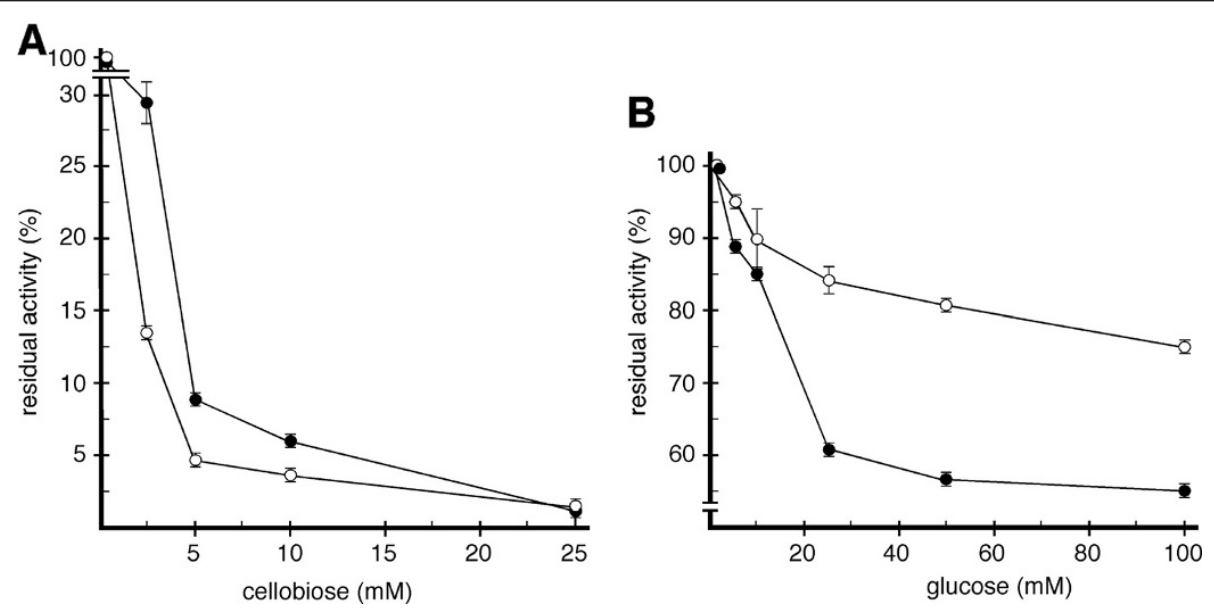

Figure 4 Inhibition of Cbh1 and CelD by cellobiose and glucose. Enzyme activity was determined with pNPC and increasing amounts of cellobiose (Panel A) or glucose (Panel B) added to Cbh1 (open symbols) or CelD (closed symbols) containing reactions. Both enzymes were inhibited by cellobiose and glucose, however Cbh1 was differentially (more resistant to) inhibited by glucose. 

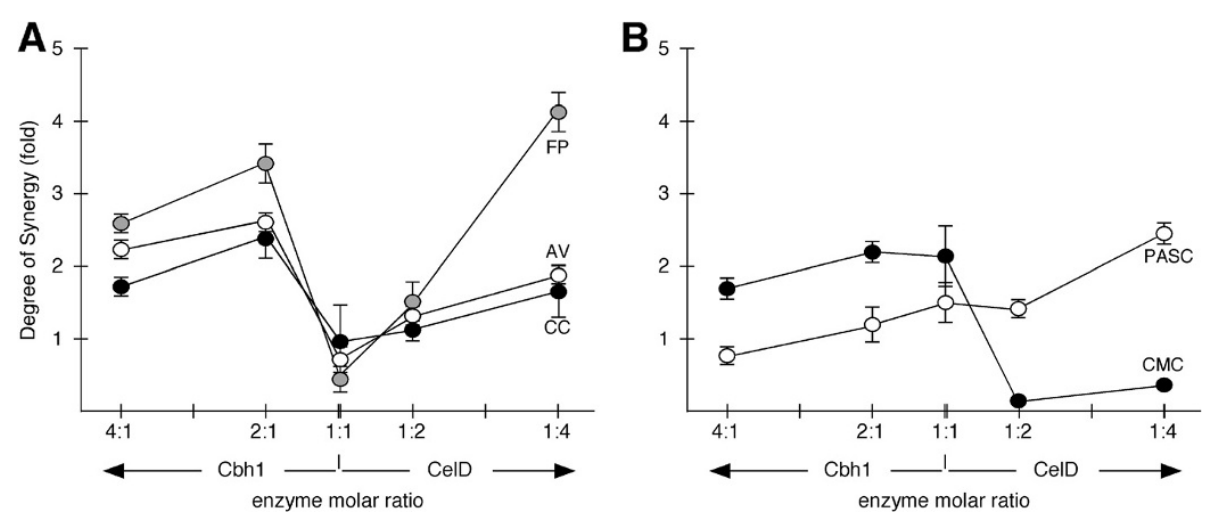

Figure 5 Molar mixtures of Cbh1 and CelD, result in a combinatorial effort to attack crystalline substrates. Panel A crystalline forms of cellulose, Avicel (AV), cotton cellulose (CC), filter paper (FP) and Panel B, partially hydrated phosphoric acid swollen Avicel (PASC) and soluble carboxymethylcellulose (CMC). $2 X$ and $4 \mathrm{X}$ molar excess of Cbh1 and CelD were incubated with various forms of cellulosic substrates and the degree of synergy $(\mathrm{ab} / \mathrm{a}+\mathrm{b})$ determined [20]. Equimolar Cbh1/CelD mixtures had no combinatorial effect (DS $\leq 1)$ on cellulose breakdown. Excess of Cbh1 over CelD resulted in a combinatorial effort (up to 345\%) to attack crystalline (A) forms of cellulose while less crystalline forms remained unchanged (B). Excess of CelD over Cbh1 resulted in little or no gain of synergy (DS up to 1.91) for crystalline (A) substrates (except 1:4 FP) and activity was inhibited with less crystalline (B) substrates. For details on activity and degree of synergy, see Additional file 3: Figure S2 and Methods.

Fungi growing in the presence of cellulose (Avicel or cotton cellulose) expressed and secreted both enzymes to the extracellular medium. Thus, we transferred both genes $c b h 1$ and celD to a controlled high-yield expression/secretion system to recover enriched and purified Cbh1 and CelD enzyme preparations useful to study their biochemical properties.

Initially we investigated enzyme thermal tolerance (Figure 3). Both enzymes were thermolabile at temperatures of $60^{\circ} \mathrm{C}$ and above. However Cbh1 appeared to be significantly more thermostable at lower temperatures, 40 and $50^{\circ} \mathrm{C}$ compared to CelD, thus indicating that the presence of a CBD provided some thermo-protection [49,50]. We then investigated the inhibition effect of cellobiose and glucose on both enzymes (Figure 4). Both enzymes were severely inhibited by cellobiose, however Cbh1 was much less sensitive to the presence of glucose (Figure 4B). It remains unclear how the presence of a CBM could affect the inhibition by glucose. However, the opened catalytic channel in the CelD catalytic channel, could explain the high sensitivity towards the presence of glucose. Interestingly, $\mathrm{Bu}$ and cols [51] while probing absolute binding free energies for cellobiose and glucose on $T$. reesei GH7-cellobiohydrolase show that glucose is less stable in the catalytic channel.

We compared specific activity and other enzyme kinetic parameters using crystalline cellulosic substrates and the artificial substrate, $p$-nitrophenyl cellobiose (Table 2 and Additional file 3: Figure S2). Cbh1 specific activity was between 16 and 4 fold more active on Avicel and cotton cellulose respectively, while CelD and Cbh1 exhibited identical specific activities when assayed with $p$ NPC (Table 2). Nearly indistinguishable specific activities with $p$ NPC highlights the fact that both enzymes have almost identical catalytic domains and the differences in activity on crystalline substrates emphasizes involvement of other structural binding features such as the CBD in Cbh1 and a lid-type open-loop structure in CelD.

Cbh $1 \mathrm{k}_{\text {cat }}$ substrate turnover rates (Table 2) were 8.47 fold higher than CelD in Avicel but only 6.05 fold higher in cotton cellulose indicating that crystalinity of the substrate had a direct effect on catalytic efficiency $\left(\mathrm{k}_{\mathrm{cat}} / \mathrm{k}_{\mathrm{m}}\right), 1.22$ versus 0.06 with Avicel and 0.98 versus 0.18 with cotton cellulose. The difference in substrate turnover rates was likely related to the presence of a CBD in Cbh1, which allowed the untying of cellulose chains from the original hydrogen bonded nanofiber while the lid-like open-loop feature on the CelD catalytic channel allowed binding and catalysis of already untied cellulose chains (Figure 1).

Thus, it seemed reasonable to assume that the amount of enzyme in the presence of a constant amount of crystalline substrate should have a synergistic effect for the protein that was capable of binding to the substrate. Indeed that was precisely what Figure 5A showed, where increasing molar amounts of Cbh1 favors specific activity over CelD, which performs at a lesser level. Therefore, protein concentration as well as substrate crystalinity differentially affects Cbh1 and CelD activity. Moreover, this could suggest some sort of interaction at the one-on-one substrate molecule level. Kurasin and Väljamäe measured Cel7A processivity and found cellulose hydrolysis was more than an order of magnitude lower than the values of the ratio of catalytic and dissociation rate constants, suggesting that the length of the obstacle-free path available for a processive run on a cellulose chain limits the 
processivity of cellobiohydrolase [52]. Igarashi and cols found that the sliding velocity of Cel7A on crystalline cellulose was $3.5 \mathrm{~nm} / \mathrm{s}$, and interestingly, the catalytic domain without a cellulose-binding domain moved at similar rates to that of the intact enzyme [53]. Moreover, Cel7A molecules slide along the crystalline cellulose surface and at a given point undergo collective halting [54,55].

In our experiment, when both enzymes were mixed at equal molecular amounts, Cbh1 and CelD probably occupied all untied cellulose chains and overall activity was reduced because of the poor performance of CelD on cellulose chains that were not loose. Excess of Cbh1 molecules rescued activity, because many Cbh1 molecules initiated fresh untying cellulosic fibers, halted and changed to a new strand allowing CelD to initiate a processive run. Thus, when both enzymes are mixed together they progress into a combinatorial effort whereas Cbh1 unties substrates chains and CelD hydrolyzes these cellulosic chains. When CelD was present in excess, the effect could only be partially overcome while CelD could not initiate new loose cellulosic chains only used the ones that were already available. Hence, the recovery of excessive CelD was dependent on the crystalinity of the substrate, less pronounced on $\mathrm{CC}$ than AV and FP showing little to no combinatorial effort effect with PASC, an artificially swollen Avicel. Activity of cellobiohydrolases on soluble (CMC) and partially hydrated substrates has been reported [56].

\section{Conclusions}

The two cellobiohydrolases investigated in this study are similar in amino acid sequence differing mainly by the presence of a cellulose-binding domain in Cbh1 which makes this enzyme a substrate bound and CelD a soluble substrate unbound enzyme. Both enzymes have similar catalytic properties however differ in thermostability, inhibition by glucose and protein concentration dependent specific activity. The fact that Cbh1 binds to its substrate and specific activity is dependent on protein concentration suggests that both enzymes employ a combinatorial effort in attacking the crystalline forms of cellulose.

\section{Methods}

\section{Materials}

Cellulosic and hemicellulosic substrates were purchased from the best source possible, Sigma Aldrich, MO and Megazyme, UK. For synthesis of APTS-labeled cellopentaose $1 \mathrm{mg}$ of cellopentaose, $\beta$-D-Glc$[1 \rightarrow 4])_{4}$-D-Glc, D(+)-cellopentaose (Sigma Aldrich, MO) was mixed with $10 \mu \mathrm{l}$ of $10 \mathrm{mg}$ APTS (8-aminopyrene-1,3,6-trisulfonic acid trisodium salt) in $200 \mu \mathrm{l}$ of $25 \%$ acetic acid and $10 \mu \mathrm{l}$ of $1 \mathrm{M}$ sodium cyanoborohydride in DMSO, heated at $80^{\circ} \mathrm{C}$ for $60 \mathrm{~min}$ and purified as described in [57]. The cellulosic substrates used throughout were carboxymethylcellulose (CMC), cotton linters,
SigmaCel50 (CC) crystalinity index (CI) of 91.2, Avicel PH$10191.7 \mathrm{CI}$ as determined by the x-ray diffraction method [58], phosphoric acid swollen-Avicel (PASC) and filter paper, Whatman \#3 (FP). Proteins were quantified by the Bradford method [59], validated for purity by SDS-PAGE [60] and used for biochemical studies.

Standard A. nidulans minimal medium (MM) and general cultivation techniques were used throughout this work and were based on $[61,62]$.

Construction of pEXPYR-client protein plasmids The pEXPYR Aspergillus "shuttle" expression plasmid for expression and secretion of client proteins was used [46]. PCR-amplified gene-fragments (for primers of gene models see Additional file 3: Figure S2) were digested with NotI and $\mathrm{XbaI}$, isolated by gel excision of a thin-slice from a $0.8 \%$ agarose electrophoresis gel, purified with QIAquick Gel Extraction kit (Quiagen), ligated onto NotI/XbaI digested pEXPYR plasmid with T4-fast ligase (Promega, WI) and transformed into $\mathrm{Ca}^{+}$competent Escherichia coli TOP 10 F' competent cells (Invitrogen, CA). Random ampicillin-resistant colonies were selected and grown in $5 \mathrm{ml}$ LB-ampicillin broth, plasmids purified [63], restricted with $\mathrm{NotI} / \mathrm{XbaI}$ and insert size verified by $1 \%$ agarose gel electrophoresis [63]. Plasmids with the correct insert size DNA were fully sequenced at the Oklahoma State University Core Facility and clones with the correct DNA sequence used for transformation. Recombinant pEXPYRCbh1 or pEXPYR-CelD plasmid was introduced through integrative transformation into the $A$. nidulans strain FGSC A773 (pyrG, pyroA) genome [64] and recombinants selected on MM supplemented with $1 \mathrm{mM}$ pyridoxine and $100 \mu \mathrm{g} / \mathrm{ml}$ of zeocin. Five pyr $\mathrm{G}^{+}$, zeocin resistant transformants were grown on $10 \mathrm{ml} \mathrm{MM}$, pyridoxine and 5\% maltose containing plates for $48 \mathrm{~h}$ at $37^{\circ} \mathrm{C}$. Accumulation of Cbh1 and CelD in the medium was analyzed by SDSPAGE and one transformant for each enzyme was used for further investigation.

Production and secretion of client proteins $10^{7}-10^{8}$ spores $/ \mathrm{ml}$ were inoculated in liquid minimal medium supplemented with 0.5 to $15 \%$ of maltose, distributed onto dishes $(20 \mathrm{ml}$ in $150 \mathrm{~mm}$ Petri-dishes and $500 \mathrm{ml}$ onto cafeteria trays) and incubated (stationary) at $37^{\circ} \mathrm{C}$ for 2-3 days. The mycelial mat was lifted with a spatula and discarded and the medium collected by filtration, centrifuged at $10,000 x \mathrm{~g}$ for $10 \mathrm{~min}$ prior to concentration by ultra-filtration (10,000 kDa cutoff Amicon), quantified by the Bradford method [59], validated for purity by SDSPAGE [60] and used for biochemical studies.

Cbh1/CelD purification For biochemical studies, the recombinant Cbh1 and CelD proteins were produced 
by heavy inoculation of fresh conidia onto Petri dishes containing MM supplemented with pyridoxine and 5\% maltose and incubated at $37^{\circ} \mathrm{C}$ for $48 \mathrm{~h}$. Cbh1 and CelD were routinely recovered with this stationary incubation method and proteolysis avoided due to the 2 day incubation period. The medium was harvested by filtration, centrifuged at $10,000 x g$ and concentrated by ultra filtration on Amicon $10 \mathrm{kDa}$ cut-off micro columns. The majority of the protein content recovered from culture filtrates was Cbh1 or CelD.

Crude ultra filtrated protein extracts were resolved by SDS-PAGE, Comassie-blue stained (CB) and the SDS removed by successive washes with $25 \%$ isopropanol solution. After transferred to $50 \mathrm{mM}$ ammonium acetate buffer pH 5.0 a $1 \%$ carboxymethylcellulose (CMC) solution was infused into the SDS-free polyacrylamide gel, incubated at $37^{\circ} \mathrm{C}$ for $120 \mathrm{~min}$, and stained with Congo red [65-68].

Cbh1 and CelD were purified by two steps. The concentrated and dialyzed protein samples $(500 \mu$ l aliquots) were applied to ion exchange Resource $\mathrm{Q}^{\circledR}$ column equilibrated with $20 \mathrm{mM}$ sodium phosphate buffer, $\mathrm{pH} 7.4$ and proteins eluted with a linear 0 to $1 \mathrm{M}$ sodium chloride gradient (Äkta Purifier, GE). Fractions active on $p$ NPC were collected and loaded onto a Superdex G- $75^{\circledR}$ $(10 \times 30 \mathrm{~mm})$ gel filtration column, equilibrated with $50 \mathrm{mM}$ ammonium acetate buffer, $\mathrm{pH} 5.0$ and eluted fractions showing enzymatic activity were analyzed by SDS-PAGE. Single band containing fractions were combined, concentrated and used for further biochemical analysis. The flow rate used for both chromatographic steps was $0.5 \mathrm{ml} \mathrm{min}{ }^{-1}$. Purified Cbh1 and CelD fractions were validated by SDS-PAGE (Additional file: 1 Table S1), and $p$ NPC, $p$ NPG activity measurement comparisons (Additional file 3: Figure S2).

Optimal $\mathrm{pH}$, temperature and thermostability Optimal pH was measured at $50^{\circ} \mathrm{C}$ in the presence of $18 \mathrm{mM}$ $p \mathrm{NPC}$ with the $\mathrm{pH}$ ranging from $\mathrm{pH} 3.0$ to $\mathrm{pH} 8.0$ using $50 \mathrm{mM}$ phosphate/citrate buffer. Optimal enzyme operating temperatures for Cbh1 and CelD were measured at their optimal $\mathrm{pH}, 5.0$, with temperatures ranging from $30^{\circ} \mathrm{C}$ to $80^{\circ} \mathrm{C}$. Thermal stability of Cbh1 and CelD was tested at optimal $\mathrm{pH}$ and exposure for various times (up to one hour). Purified enzyme in $50 \mathrm{mM}$ ammonium acetate (without substrate) was incubated at temperatures ranging from 40 to $70^{\circ} \mathrm{C}$. Samples were drawn from a master mix and residual activity assayed with $18 \mathrm{mM}$ $p$ NPC.

Cellulose specific CelD or Cbh1, CBD-dependent binding To reveal the functionality and specificity of the predicted CBM1 domain, the binding of Cbh1 or CelD was evaluated by a pull-down assay. $20 \mu \mathrm{g}$ of Cbh1 or
CelD was incubated at $4 \mathrm{C}$ for $30 \mathrm{~min}$ in a rotary shaker, with $200 \mu \mathrm{l}$ of $30 \%$ cotton cellulose or Avicel slurry in $50 \mathrm{mM}, \mathrm{pH}$ 5.0, ammonium acetate buffer. The reaction was centrifuged at $14,000 \times \mathrm{xg}$ for $15 \mathrm{~min}$, supernatant (free fraction) collected and concentrated in an Amicon, $10 \mathrm{kDa}$ cutoff ultra filtration column mixed with 2X Laemmli buffer and subjected to SDS-PAGE. The bound fraction was released from the Avicel or cotton linter or Avicel slurry by addition of $40 \mu \mathrm{l}$ of 2X Laemmli buffer, vigorous agitation and boiling for $10 \mathrm{~min}$. The SDS protein-solubilized slurry was centrifuged and supernatant (bound fraction) subjected to SDS-PAGE.

Cellobiohydrolase activities, substrate- and proteindependent kinetics Substrate specificity of cellobiohydrolases was determined by incubating $1 \mu \mathrm{g}$ of Cbh1 or CelD with a, $1 \%$ slurry of cotton cellulose (Sigmacell 50), Avicel PH-101, PASC or $1 \%$ solution of CMC or $18 \mathrm{mM} p$ NPCellobiose, incubated for $120 \mathrm{~min}$ or as indicated at $50^{\circ} \mathrm{C}$ and the release of reducing sugars determined with the DNS method [69]. Specific activity was defined as $U$ per mg protein at $50^{\circ} \mathrm{C}$ whereas $\mathrm{U}$ was the amount of enzyme that produced $1 \mu$ mole of reducing sugar (glucose or cellobiose) per minute. Activity towards starch, polygalacturonic acid, wheat arabinoxylan, arabinan from sugar beet, xylan birchwood, xylan beechwood and xyloglucan from tamarind could not be detected and is not shown.

Michaelis-Menten kinetic constants were determined from Lineweaver-Burk plots. Reaction rates were measured using Avicel and cotton cellulose ranging from 0 to $100 \mathrm{mg} / \mathrm{ml}$ of insoluble substrate suspended in $50 \mathrm{mM}$ ammonium acetate buffer $\mathrm{pH}$ 5.0. Reactions were carried out over a $120-\mathrm{min}$ period at $50^{\circ} \mathrm{C}$, boiled, and the released reducing sugars determined by DNS assay [69]. The raw substrate activity plots are shown in Additional file 4: Figure S3.

The degree of synergy (D.S.) was calculated by dividing the activity when Cbh1 and CelD were incubated together $(a b)$ by the sum of the activity when Cbh1 and CelD were incubated separately $(a+b)$ as proposed by [70]. Enzyme mixtures with dissimilar molar amounts (e.g., 4xCbh1:1xCelD), the individual activities were adjusted correspondingly $(4 a+1 b)$. A value of $>1$ indicated synergy and a value below 1 indicated antagonist competition for the same substrate molecules.

Homology molecular modeling The atomic coordinates of the cellobiohydrolase I (CBH IB) from Talaromyces emersonii (PDBID: 1Q9H, [47]) was used as template for generating structural models of both $\mathrm{CBHI}$ and CelD by restraint-based modeling as implemented in the program MODELLER [71]. To guarantee sufficient conformational 
sampling, an ensemble of 50 models was built, from which the best final model was selected based on evaluation of stereo chemical values from MOLPROBITY [72], the objective function from MODELLER (DOPE score) and by visual inspection. Those models were then minimized using the steepest descent minimization algorithm as implemented in the UCSF chimera software [73]. Incomplete side-chains were replaced using the Dunbrack rotamer library [74].

Cellobiose and glucose Inhibition To analyze Cbh1 and CelD inhibition, $1 \mu \mathrm{g}$ enzyme was incubated in $18 \mathrm{mM}$ $p \mathrm{NPC}$ dissolved in $50 \mathrm{mM}$ ammonium acetate buffer $\mathrm{pH}$ 5.0 with glucose or cellobiose added in a range from 0 to $100 \mathrm{mM}$ at $50^{\circ} \mathrm{C}$. After $15 \mathrm{~min}$, enzyme activity was stopped by adding $100 \mu \mathrm{l}$ of a $2 \% \mathrm{Na}_{2} \mathrm{CO}_{3}$. The $p$ NPC chromophore release was spectrophotometrically quantified at $410 \mathrm{~nm}$ with a Multimode Infinte M200 Reader (Tecan, SC).

\section{Additional files}

Additional file 1: Table S1. Primers used in this study. Table S2. Cbh1 and CelD substrate binding competition. Table S3. Cbh1 and CelD pNPC and $p N P G$ activity

Additional file 2: Figure S1. Time course A. nidulans client expression and secretion of A. niveus Cbh1 (A) and CelD (B) and purified enzymes (C). Note that after the second day native Cbh1 and CelD are subjected to proteolytic degradation in the medium.

Additional file 3: Figure S2. Cellobiohydrolase substrate dependent kinetics with crystalline cellulosic fibers. Michaelis-Menten substrate dependent, avicel (open symbols) and cotton linters (closed) cellobiohydrolase activity of Cbh1 (A) and CeID (B). Nearly equal amounts of enzyme (9.3 nM Cbh1 and $10.7 \mathrm{nM}$ CelD) were incubated with increasing amounts of substrate, avicel or cotton linters and specific velocity $(\mu \mathrm{mol} / \mathrm{min})$ determined after a $120 \mathrm{~min}$ reaction period at $40 \mathrm{C}$.

Additional file 4: Figure S3. Cbh1 and CelD differential thermal inactivation

\begin{abstract}
Abbreviations
CaZy: Carbohydrate-Active enZYmes Database (http://www.cazy.org/); Cbh1: CaZy GH7 (Cel7A) cellobiohydrolase 1; CelD: CaZy GH7 (Cel7B) cellobiohydrolase D; Cl: Crystalinity index; CD: Catalytic domain; CBD: Cellulose-binding domain; CMC: Carboxymethylcellulose; AV: Avicel; CC: Cotton cellulose; DNS: Dintrosalicilic acid; DS: Degree of synergism; FP: Whatman \#3 filter paper; MM: Minimal Aspergillus medium; pNPC: Paranitrophenylcellobiose; $p$ NPG: Para-nitophenylglucose; PASC: Phosphoric acid swollen (Avicel) cellulose; SDS-PAGE: Sodium dodecyl sulfate polyacrylamide gel electrophoresis.
\end{abstract}

\section{Competing interests}

The authors are not aware of any affiliations, memberships, funding, or financial holdings that might be perceived as affecting the objectivity of this article.

\section{Acknowledgements}

We are indebted for insightful discussions with Dr. Babu Fathepure and Dr. Richard J Ward, the expert enzyme kinetic analysis prepared by Junio Cota, at the Brazilian Bioethanol Science and Technology Laboratory and generous funding from the Oklahoma Bioenergy Center and Department of Energy, awards 06103-OKL and ZDJ-7-77608-01 and FAPESP award 2010/18198-3.

\section{Author details}

${ }^{1}$ Department of Microbiology \& Molecular Genetics, Oklahoma State University, Stillwater, OK, USA. ${ }^{2}$ Department of Biochemistry and Molecular Biology, Oklahoma State University, Stillwater, OK, USA. ${ }^{3}$ Laboratório Nacional de Biociências (LNBio), Campinas, Sao Paulo, Brazil. " Laboratório Nacional de Ciência e Tecnologia do Bioetanol (CTBE), Centro Nacional de Pesquisas em Energia e Materiais, Campinas, Sao Paulo, Brazil. ${ }^{5}$ Department of Biochemistry, Ribeirão Preto School of Medicine, Ribeirão Preto, Sao Paulo, Brazil. ${ }^{6}$ Biology Department, FFCLRP, Universidade de São Paulo, Ribeirão Preto, Sao Paulo, Brazil.

\section{Authors' contributions}

Conceived and designed the experiments: RAP, MLTMP and AM. Made the 3D-structural modeling: MTM and FMS. Performed the experiments: ARLD, FS and TAG and contributed equally to this work. Analyzed the data: FS, ARLD, TAG, RAP and MTM. Wrote the paper: RAP, ARLD, FS, FMS, MLTMP and MTM. All authors read and approved the final manuscript.

Received: 14 December 2011 Accepted: 30 March 2012

Published: 11 April 2012

\section{References}

1. Himmel ME, Ding SY, Johnson DK, Adney WS, Nimlos MR, Brady JW, Foust TD: Biomass recalcitrance: engineering plants and enzymes for biofuels production. Science 2007, 315(5813):804-807.

2. Chundawat SP, Bellesia G, Uppugundla N, da Costa Sousa L, Gao D, Cheh AM, Agarwal UP, Bianchetti CM, Phillips GN Jr, Langan P, et al: Restructuring the crystalline cellulose hydrogen bond network enhances its depolymerization rate. J Am Chem Soc 2011, 133(29):11163-11174.

3. Bayer EA, Lamed R, Himmel ME: The potential of cellulases and cellulosomes for cellulosic waste management. Curr Opin Biotechnol 2007, 18(3):237-245.

4. Chundawat SPS, Beckham GT, Himmel ME, Dale BE: Deconstruction of Lignocellulosic Biomass to Fuels and Chemicals. Annual Review of Chemical and Biomolecular Engineering 2011, 2(1):121-145.

5. Akin DE, Morrison WH 3rd, Rigsby LL, Barton FE 2nd, Himmelsbach DS, Hicks KB: Corn stover fractions and bioenergy: chemical composition, structure, and response to enzyme pretreatment. Appl Biochem Biotechnol 2006, 129-132:104-116.

6. Ding SY, Xu Q, Ali MK, Baker JO, Bayer EA, Barak Y, Lamed R, Sugiyama J, Rumbles G, Himmel ME: Versatile derivatives of carbohydrate-binding modules for imaging of complex carbohydrates approaching the molecular level of resolution. Biotechniques 2006, 41(4):435-436. 438, 440 passim.

7. Harris D, DeBolt S: Relative crystallinity of plant biomass: studies on assembly, adaptation and acclimation. PLoS One 2008, 3(8):e2897.

8. Binder JB, Raines RT: Fermentable sugars by chemical hydrolysis of biomass. Proc Natl Acad Sci U S A 2010, 107(10):4516-4521.

9. Miller EN, Jarboe LR, Turner PC, Pharkya P, Yomano LP, York SW, Nunn D, Shanmugam KT, Ingram LO: Furfural inhibits growth by limiting sulfur assimilation in ethanologenic Escherichia coli strain LY180. Appl Environ Microbiol 2009, 75(19):6132-6141.

10. Gaunt JL, Lehmann J: Energy balance and emissions associated with biochar sequestration and pyrolysis bioenergy production. Environ Sci Technol 2008, 42(11):4152-4158.

11. Khiyami MA, Pometto lii AL, Brown RC: Detoxification of corn stover and corn starch pyrolysis liquors by Pseudomonas putida and Streptomyces setonii suspended cells and plastic compost support biofilms. J Agric Food Chem 2005, 53(8):2978-2987.

12. Macarron R, Acebal C, Castillon MP, Dominguez JM, de la Mata I, Pettersson G, Tomme P, Claeyssens M: Mode of action of endoglucanase III from Trichoderma reesei. Biochem J 1993, 289(Pt 3):867-873.

13. Macarron R, van Beeumen J, Henrissat B, de la Mata I, Claeyssens M: Identification of an essential glutamate residue in the active site of endoglucanase III from Trichoderma reesei. FEBS Lett 1993, 316(2):137-140.

14. McCarthy T, Hanniffy O, Savage AV, Tuohy MG: Catalytic properties and mode of action of three endo-beta-glucanases from Talaromyces emersonii on soluble beta-1,4- and beta-1,3;1,4-linked glucans. Int J Biol Macromol 2003, 33(1-3):141-148. 
15. Baker JO, Ehrman Cl, Adney WS, Thomas SR, Himmel ME: Hydrolysis of cellulose using ternary mixtures of purified cellulases. Appl Biochem Biotechnol 1998, 70-72:395-403.

16. Nimlos MR, Matthews JF, Crowley MF, Walker RC, Chukkapalli G, Brady JW, Adney WS, Cleary JM, Zhong L, Himmel ME: Molecular modeling suggests induced fit of Family I carbohydrate-binding modules with a brokenchain cellulose surface. Protein Eng Des Sel 2007, 20(4):179-187.

17. Yaoi K, Kondo H, Hiyoshi A, Noro N, Sugimoto H, Tsuda S, Mitsuishi $Y$, Miyazaki K: The structural basis for the exo-mode of action in $\mathrm{GH} 74$ oligoxyloglucan reducing end-specific cellobiohydrolase. J Mol Biol 2007, 370(1):53-62.

18. Nunoura N, Ohdan K, Tanaka K, Tamaki H, Yano T, Inui M, Yukawa H, Yamamoto K, Kumagai $\mathrm{H}$ : Cloning and nucleotide sequence of the betaD-glucosidase gene from Bifidobacterium breve $\mathrm{clb}$, and expression of beta-D-glucosidase activity in Escherichia coli. Biosci Biotechnol Biochem 1996, 60(12):2011-2018.

19. Nunoura N, Ohdan K, Yano T, Yamamoto K, Kumagai H: Purification and characterization of beta-D-glucosidase (beta-D-fucosidase) from Bifidobacterium breve clb acclimated to cellobiose. Biosci Biotechnol Biochem 1996, 60(2):188-193.

20. Sigurskjold BW, Duus B, Bock K: Hydrolysis of substrate analogues catalysed by beta-D-glucosidase from Aspergillus niger. Part II: Deoxy and deoxyhalo derivatives of cellobiose. Acta Chem Scand 1991, 45(10):1032-1041.

21. Boisset C, Fraschini C, Schulein M, Henrissat B, Chanzy H: Imaging the enzymatic digestion of bacterial cellulose ribbons reveals the endo character of the cellobiohydrolase Cel6A from Humicola insolens and its mode of synergy with cellobiohydrolase Cel7A. Appl Environ Microbiol 2000, 66(4):1444-1452

22. Jeoh T, Wilson DB, Walker LP: Cooperative and competitive binding in synergistic mixtures of Thermobifida fusca cellulases Cel5A, Cel6B, and Cel9A. Biotechnol Prog 2002, 18(4):760-769.

23. Mishra C, Rao M: Mode of action and synergism of cellulases from Penicillium funiculosum. App/ Biochem Biotechnol 1988, 19(2):139-150.

24. Henrissat B, Callebaut I, Fabrega S, Lehn P, Mornon JP, Davies G: Conserved catalytic machinery and the prediction of a common fold for several families of glycosyl hydrolases. Proc Natl Acad Sci U S A 1995, 92(15):7090-7094.

25. Zhong L, Matthews JF, Hansen PI, Crowley MF, Cleary JM, Walker RC, Nimlos MR, Brooks CL 3rd, Adney WS, Himmel ME, et al: Computational simulations of the Trichoderma reesei cellobiohydrolase I acting on microcrystalline cellulose Ibeta: the enzyme-substrate complex. Carbohydr Res 2009, 344(15):1984-1992.

26. Boisset $C$, Petrequin $C$, Chanzy $H$, Henrissat B, Schulein M: Optimized mixtures of recombinant Humicola insolens cellulases for the biodegradation of crystalline cellulose. Biotechnol Bioeng 2001, 72(3):339345 .

27. Davies $G$, Henrissat B: Structures and mechanisms of glycosyl hydrolases. Structure 1995, 3(9):853-859.

28. Kipper $K$, Valjamae $P$, Johansson G: Processive action of cellobiohydrolase Cel7A from Trichoderma reesei is revealed as 'burst' kinetics on fluorescent polymeric model substrates. Biochem J 2005, 385(Pt 2):527535.

29. Murashima K, Kosugi A, Doi RH: Determination of subunit composition of Clostridium cellulovorans cellulosomes that degrade plant cell walls. App/ Environ Microbiol 2002, 68(4):1610-1615.

30. Palonen $\mathrm{H}$, Tenkanen M, Linder M: Dynamic interaction of Trichoderma reesei cellobiohydrolases Cel6A and Cel7A and cellulose at equilibrium and during hydrolysis. Appl Environ Microbiol 1999, 65(12):5229-5233.

31. Rouvinen J, Bergfors T, Teeri T, Knowles JK, Jones TA: Three-dimensional structure of cellobiohydrolase II from Trichoderma reesei. Science 1990, 249(4967):380-386.

32. Zhang $Y H$, Lynd LR: A functionally based model for hydrolysis of cellulose by fungal cellulase. Biotechnol Bioeng 2006, 94(5):888-898.

33. Divne C, Stahlberg J, Reinikainen T, Ruohonen L, Pettersson G, Knowles JK, Teeri $\Pi$, Jones TA: The three-dimensional crystal structure of the catalytic core of cellobiohydrolase I from Trichoderma reesei. Science 1994, 265 (5171):524-528.

34. Divne C, Stahlberg J, Teeri TT, Jones TA: High-resolution crystal structures reveal how a cellulose chain is bound in the $50 \mathrm{~A}$ long tunnel of cellobiohydrolase I from Trichoderma reesei. J Mol Biol 1998 275(2):309-325.
35. Mackenzie LF, Sulzenbacher G, Divne C, Jones TA, Woldike HF, Schulein M, Withers SG, Davies GJ: Crystal structure of the family 7 endoglucanase I (Cel7B) from Humicola insolens at $2.2 \mathrm{~A}$ resolution and identification of the catalytic nucleophile by trapping of the covalent glycosyl-enzyme intermediate. Biochem J 1998, 335(Pt 2):409-416.

36. Teeri TT, Koivula A, Linder M, Wohlfahrt G, Divne C, Jones TA: Trichoderma reesei cellobiohydrolases: why so efficient on crystalline cellulose? Biochem Soc Trans 1998, 26(2):173-178.

37. Varrot A, Hastrup S, Schulein M, Davies GJ: Crystal structure of the catalytic core domain of the family 6 cellobiohydrolase II, Cel6A, from Humicola insolens, at 1.92 A resolution. Biochem J 1999, 337(Pt 2):297-304.

38. Varrot A, Schulein M, Davies GJ: Structural changes of the active site tunnel of Humicola insolens cellobiohydrolase, Cel6A, upon oligosaccharide binding. Biochemistry 1999, 38(28):8884-8891.

39. Zou J, Kleywegt GJ, Stahlberg J, Driguez H, Nerinckx W, Claeyssens M, Koivula A, Teeri TT, Jones TA: Crystallographic evidence for substrate ring distortion and protein conformational changes during catalysis in cellobiohydrolase Ce16A from trichoderma reesei. Structure 1999, 7 (9):1035-1045.

40. Beckham GT, Matthews JF, Bomble YJ, Bu L, Adney WS, Himmel ME, Nimlos MR, Crowley MF: Identification of amino acids responsible for processivity in a Family 1 carbohydrate-binding module from a fungal cellulase. $J$ Phys Chem B 2010, 114(3):1447-1453.

41. Wang $L$, Zhang $Y$, Gao P: A novel function for the cellulose binding module of cellobiohydrolase I. Sci China C Life Sci 2008, 51(7):620-629.

42. Bu L, Beckham GT, Crowley MF, Chang CH, Matthews JF, Bomble YJ, Adney WS, Himmel ME, Nimlos MR: The energy landscape for the interaction of the family 1 carbohydrate-binding module and the cellulose surface is altered by hydrolyzed glycosidic bonds. J Phys Chem B 2009, 113(31):10994-11002.

43. Sato S, LiU F, KoC H, Tien M: Expression analysis of extracellular proteins from Phanerochaete chrysosporium grown on different liquid and solid substrates. Microbiology 2007, 153(Pt 9):3023-3033.

44. Tolonen AC, Haas W, Chilaka AC, Aach J, Gygi SP, Church GM: Proteomewide systems analysis of a cellulosic biofuel-producing microbe. Mol Syst Biol 2011, 7:461.

45. Payne GA, Nierman WC, Wortman JR, Pritchard BL, Brown D, Dean RA, Bhatnagar D, Cleveland TE, Machida M, Yu J: Whole genome comparison of Aspergillus flavus and A. oryzae. Medical Mycology 2006, 44(s1):9-11.

46. Segato F, Damasio ARL, Gonçalvez TA, de Lucas RC, Squina FM, Decker SR, Prade RA: High-yield secretion of multiple proteins in Aspergillus. Enzime Microbiol Technol 2012, 51(2):100-106.

47. Grassick A, Murray PG, Thompson R, Collins CM, Byrnes L, Birrane G, Higgins TM, Tuohy MG: Three-dimensional structure of a thermostable native cellobiohydrolase, $\mathrm{CBH}$ IB, and molecular characterization of the cel7 gene from the filamentous fungus, Talaromyces emersonii. Eur J Biochem 2004, 271(22):4495-4506

48. Santos CR, Tonoli CC, Trindade DM, Betzel C, Takata H, Kuriki T, Kanai T, Imanaka T, Arni RK, Murakami MT: Structural basis for branching-enzyme activity of glycoside hydrolase family 57 : structure and stability studies of a novel branching enzyme from the hyperthermophilic archaeon Thermococcus kodakaraensis KOD1. Proteins 2011, 79(2):547-557.

49. Hall M, Rubin J, Behrens SH, Bommarius AS: The cellulose-binding domain of cellobiohydrolase Cel7A from Trichoderma reesei is also a thermostabilizing domain. J Biotechnol 2011, 155(4):370-376.

50. Souza TA, Santos CR, Souza AR, Oldiges DP, Ruller R, Prade RA, Squina FM, Murakami MT: Structure of a novel thermostable GH51 alpha-Larabinofuranosidase from Thermotoga petrophila RKU-1. Protein Sci 2011, 20(9):1632-1637.

51. Bu L, Beckham GT, Shirts MR, Nimlos MR, Adney WS, Himmel ME, Crowley MF: Probing carbohydrate product expulsion from a processive cellulase with multiple absolute binding free energy methods. J Biol Chem 2011, 286(20):18161-18169.

52. Kurasin $M$, Valjamae $P$ : Processivity of cellobiohydrolases is limited by the substrate. J Biol Chem 2011, 286(1):169-177.

53. Igarashi K, Koivula A, Wada M, Kimura S, Penttila M, Samejima M: High speed atomic force microscopy visualizes processive movement of Trichoderma reesei cellobiohydrolase I on crystalline cellulose. J Biol Chem 2009, 284(52):36186-36190. 
54. Igarashi K, Uchihashi T, Koivula A, Wada M, Kimura S, Okamoto T, Penttila M, Ando T, Samejima M: Traffic jams reduce hydrolytic efficiency of cellulase on cellulose surface. Science 2011, 333(6047):1279-1282.

55. Fox JM, Levine SE, Clark DS, Blanch HW: Initial- and processive-cut products reveal cellobiohydrolase rate limitations and the role of companion enzymes. Biochemistry 2012, 51(1):442-452

56. Gilkes NR, Kwan E, Kilburn DG, Miller RC, Warren RAJ: Attack of carboxymethylcellulose at opposite ends by two cellobiohydrolases from Cellulomonas fimi. Journal of Biotechnology 1997, 57(1-3):83-90.

57. Naran R, Pierce ML, Mort AJ: Detection and identification of rhamnogalacturonan lyase activity in intercellular spaces of expanding cotton cotyledons. Plant J 2007, 50(1):95-107.

58. Park S, Baker JO, Himmel ME, Parilla PA, Johnson DK: Cellulose crystallinity index: measurement techniques and their impact on interpreting cellulase performance. Biotechnology for biofuels 2010, 3(1):10.

59. Marshall T, Williams KM: Coomassie blue protein dye-binding assays measure formation of an insoluble protein-dye complex. Anal Biochem 1992, 204(1):107-109.

60. Shapiro AL, Vinuela E, Maizel JV Jr: Molecular weight estimation of polypeptide chains by electrophoresis in SDS-polyacrylamide gels. Biochem Biophys Res Commun 1967, 28(5):815-820.

61. Pontecorvo G, Roper JA, Hemmons LM, McDonald KD, Bufton AWJ: The genetics ofAspergillus nidulans. Adv Genet 1953, 5:141-238.

62. Clutterbuck AJ: Sexual and parasexual genetics of Aspergillus species. Biotechnology 1992, 23:3-18.

63. JSambrookEFFritschTManiatis1987Molecular cloning: A laboratory manual 2nd ednCold Spring HarberSambrook J, Fritsch EF, Maniatis T: Molecular cloning: A laboratory manual, 2nd edn.: Cold Spring Harber; 1987.

64. Yelton MM, Hamer JE, Timberlake WE: Transformation of Aspergillus nidulansby using atrpCplasmid. Proc Natl Acad Sci U S A 1984, 81(5):14701474.

65. Mathew R, Rao KK: Activity staining of endoglucanases in polyacrylamide gels. Anal Biochem 1992, 206(1):50-52.

66. Schwarz WH, Bronnenmeier K, Grabnitz F, Staudenbauer WL: Activity staining of cellulases in polyacrylamide gels containing mixed linkage beta-glucans. Anal Biochem 1987, 164(1):72-77.

67. Bartley TD, Murphy-Holland K, Eveleigh DE: A method for the detection and differentiation of cellulase components in polyacrylamide gels. Anal Biochem 1984, 140(1):157-161.

68. Beguin P: Detection of cellulase activity in polyacrylamide gels using Congo red-stained agar replicas. Anal Biochem 1983, 131(2):333-336.

69. Miller GL: Use of dintirosalicilic acid reagent for determination of reducing sugar. Analytical Chemistry 1959, 31:426-428.

70. Srisodsuk M, Kleman-Leyer K, Keranen S, Kirk TK, Teeri T: Modes of action on cotton and bacterial cellulose of a homologous endoglucanaseexoglucanase pair from Trichoderma reesei. Eur J Biochem 1998, 251 (3):885-892.

71. Fiser A, Sali A: Modeller: generation and refinement of homology-based protein structure models. Methods Enzymol 2003, 374:461-491.

72. Chen VB, Arendall WB 3rd, Headd JJ, Keedy DA, Immormino RM, Kapral GJ, Murray LW, Richardson JS, Richardson DC: MolProbity: all-atom structure validation for macromolecular crystallography. Acta Crystallogr D Biol Crystallogr 2010, 66(Pt 1):12-21.

73. Pettersen EF, Goddard TD, Huang CC, Couch GS, Greenblatt DM, Meng EC, Ferrin TE: UCSF Chimera-a visualization system for exploratory research and analysis. J Comput Chem 2004, 25(13):1605-1612.

74. Dunbrack RL Jr, Cohen FE: Bayesian statistical analysis of protein sidechain rotamer preferences. Protein Sci 1997, 6(8):1661-1681.

doi:10.1186/1754-6834-5-21

Cite this article as: Segato et al:: Two structurally discrete GH7cellobiohydrolases compete for the same cellulosic substrate fiber. Biotechnology for Biofuels 2012 5:21.

\section{Submit your next manuscript to BioMed Central and take full advantage of:}

- Convenient online submission

- Thorough peer review

- No space constraints or color figure charges

- Immediate publication on acceptance

- Inclusion in PubMed, CAS, Scopus and Google Scholar

- Research which is freely available for redistribution

Submit your manuscript at www.biomedcentral.com/submit
C Biomed Central 